\title{
ENHANCING INFLAMMATORY AND CHEMOTACTIC SIGNALS TO REGULATE BONE REGENERATION
}

\author{
E.M. Czekanska ${ }^{1,2}$, J.R. Ralphs ${ }^{2}$, M. Alini ${ }^{1}$ and M.J. Stoddart ${ }^{1, *}$ \\ ${ }^{1}$ AO Research Institute Davos, AO Foundation, Davos, Switzerland \\ ${ }^{2}$ Cardiff School of Biosciences, Cardiff University, Cardiff, UK
}

\begin{abstract}
Stem cells have become the fundamental element in regenerative medicine due to their inherent potential to differentiate into various cell types, and the ability to produce various bioactive molecules, including growth factors, cytokines and extracellular matrix molecules. In vivo, the secretion of tropic factors is modulated by chemotactic and inflammatory factors. In this study, we analysed the influence of a $2 \mathrm{~h}$ stimulation of mesenchymal stem cells (MSCs) with interleukin-1 $\beta$ (IL1 $\beta$ ), granulocytecolony stimulating factor (GCSF), stromal cell-derived factor 1 (SDF1) and stem cell factor (SCF). Our results demonstrated that this short stimulation exerts pronounced effects on the expression of multiple cytokine genes and proteins in MSC cells 48 and $72 \mathrm{~h}$ later. IL1 $\beta$ strongly promoted the secretion of a wide range of proteins with chemotactic, proinflammatory and angiogenic properties, whereas SCF regulated the expression of proteins involved in proliferation, chondrogenesis and ECM regulation. This demonstrates that the changes in secretome can be directed towards a desired final functional outcome by selection of the most appropriate cytokine. Moreover, the expression pattern of Wnt signalling pathway components suggested the differential regulation of this pathway by IL1 $\beta$ and SCF. Altogether, the robust paracrine action of MSCs can be achieved within a just $2 \mathrm{~h}$ treatment, which would be feasible within the operating theatre during a single surgical procedure. These results suggest that integrating inflammatory modulation in bone tissue engineering, by modifying the MSC secretome by way of a short stimulus, would provide a more targeted approach than administering unmodified MSCs alone.
\end{abstract}

Keywords: Bone repair, stem cells, cytokines, inflammation, tissue engineering.

*Address for correspondence:

Martin J. Stoddart

AO Research Institute

Clavadelerstrasse 8

CH 7270-Davos Platz

Switzerland

Telephone Number: $+41(0) 814142448$

E-Mail: martin.stoddart@aofoundation.org

\section{Introduction}

Various strategies have been developed and applied to aid the regeneration process of the injured tissue. These include separate or combined implantation of specific cell types, biomaterials and factors. Cell therapy alone, or in combination with supportive biomaterials and factors, is of particular interest for clinical application to treat a wide array of acute or chronic conditions due to the inherent potential of stem cells to differentiate into various cell types (Pittenger et al., 1999). Currently, more than 4,500 ongoing clinical trials have been registered worldwide (www.clinicaltrail.gov) using stem cells, and approximately $10 \%$ of these use MSCs. Specifically, much attention and hope is invested into single surgical procedure cell therapies. This strategy integrates the autologous cell harvesting, processing and re-implantation into the injured site within the operation theatre. Intraoperative autologous stem cell therapy brings advantages regarding the usage of patient's own cells, thus avoiding the activation of an immune response, extensive in vitro cell expansion and manipulation, requirements for Good Manufacture Practice facilities, a secondary invasive procedure and potential contamination (Coelho et al., 2012).

In addition to their direct contribution to tissue regeneration, as a consequence of differentiation into specific phenotype, implanted cells aid regeneration by producing various bioactive molecules, including growth factors, cytokines and extracellular matrix molecules (Tsiridis et al., 2007; Zhukareva et al., 2010; Hsiao et al., 2012). These secreted factors act in an auto- and paracrine manner regulating cell phenotype. The importance of paracrine actions in the host tissue have been studied extensively in repair and regeneration of the central nervous system (Drago et al., 2013), heart (Gnecchi et al., 2006; Hwang et al., 2012) and skin (Schlosser et al., 2012). The indirect action of progenitor cells implanted within the bone-healing environment is less understood; nevertheless, the importance of various factors secreted by cells present in fracture milieu is known to have great importance on bone regeneration.

The importance of inflammation occurring after bone fracture has been demonstrated directly by the increased levels of various factors at the molecular and protein level, as well as indirectly by removing the fracture haematoma (Kolar et al., 2011). Combating inflammation and, as consequence, the wide spectrum of factors secreted by immune and progenitor cells present at the fracture site has also been shown to have a role (Simon et al., 2002). The local increased levels of mRNA expression of interleukin 8 (IL8), vascular endothelial growth factor (VEGF) together 
with interleukin 6 (IL6), CXC chemokine receptor type 4 (CXCR4) and secreted phosphoprotein 1 (SPP1) in fracture haematoma indicate their importance for chemotaxis, angiogenesis and osteogenesis (Kolar et al., 2011).

The removal of the haematoma, together with cells contained within, or combating inflammation with nonsteroid anti-inflammatory drugs, prolonged the time of fracture healing compared to fracture with haematoma (Simon et al., 2002; Kolar et al., 2011; Mountziaris et al., 2011).

In order to increase the production of specific factors by cells strategies such as genetic engineering and preconditioning of cells have been applied. Since the secretion of tropic factors is modulated in vivo by cytokines, their use could provide a strategy to enhance the paracrine actions of cells prior to their implantation. This could enhance their function during the critical early time points. Driven by this hypothesis we selected four factors which are players in the early stages of the bone healing cascade, including interleukin $1 \beta$ (IL1 $\beta$ ), granulocyte-colony stimulating factor (GCSF), stromal cell-derived factor 1 (SDF1) and stem cell factor (SCF), to determine the cytokine profile of mesenchymal stem cells (MSCs) after transient stimulation with these factors. IL1 $\beta$ would be expected to lead to a change in the expression of inflammatory modifying cytokines. SDF1 was chosen as it is known for its effects on chemotaxis, but little is known about whether the factor changes the phenotype of the cells as well. GCSF and CSF have been proposed in rabbits to be involved in proliferation and self-renewal (Tang et al., 2009), and so would be expected to cause the release of mitogenic factors.

\section{Materials and Methods}

\section{Human bone marrow MSCs isolation}

Human bone marrow aspirates were obtained from the iliac crest of nine patients following ethical approval (KEK-ZHNr: 2010-04444/0) and with the written consent of donors. Nine donors were used (Mean age: 43 years; range: 18-65 years; 7 females and 2 males, Table 1). Mesenchymal stem cells (MSCs) were isolated and expanded as previously described (Li et al., 2009). In brief, the mononuclear cell fraction of whole marrow aspirate was isolated using a Ficol density gradient. Isolated cells were seeded at a density of $\sim 50,000$ cells $/ \mathrm{cm}^{2}$ in $\alpha$-Minimal Essential Medium ( $\alpha$ MEM, Gibco/Life Technologies) medium with 10\% MSC tested serum (Biochrom/Merck, Darmstadt, Germany) $+5 \mathrm{ng} / \mathrm{mL}$ basic fibroblast growth factor (bFGF,
Table 1. Human bone marrow-derived MSCs' donor information.

\begin{tabular}{|c|c|c|}
\hline Donor \# & Gender & Age \\
\hline 1 & female & 65 \\
\hline 2 & male & 41 \\
\hline 3 & female & 64 \\
\hline 4 & female & 40 \\
\hline 5 & female & 18 \\
\hline 6 & female & 20 \\
\hline 7 & female & 40 \\
\hline 8 & male & 41 \\
\hline 9 & female & 55 \\
\hline
\end{tabular}

Fitzgerald Industries International). Cells were left to attach for 4 days and the medium is then replaced three times per week. Cells were harvested by trypsinisation at 60-80\% confluence and reseeded at 3000 cells $/ \mathrm{cm}^{2}$. Cells from all donors were tested to confirm differentiation potential into chondrocytes, adipocytes and osteoblasts (data not shown).

\section{MSCs stimulation}

MSCs $(6.082 \pm 0.83$ population doublings after cryopreservation) were plated at a density of 15,000 cells $/ \mathrm{cm}^{2}$ in cell culture polystyrene flasks and cultured in Dulbecco's Modified Eagle's Medium (DMEM) low glucose (Gibco/Life Technologies/Thermo Fisher Scientific, Zug, Switzerland) supplemented with $10 \%$ FCS (Gibco/Life Technologies) and 1\% penicillin/streptomycin (Gibco/Life Technologies) overnight. Two experimental designs for cell stimulation were applied as presented in Fig. 1. On the day of stimulation, medium was aspirated and fresh medium containing $10 \mathrm{ng} / \mathrm{mL}$ IL1 $\beta, 100 \mathrm{ng} /$ $\mathrm{mL} \mathrm{SCF}, 100 \mathrm{ng} / \mathrm{mL}$ GCSF or $1 \mu \mathrm{g} / \mathrm{mL}$ SDF1 (all from PromoCell, Heidelberg, Germany) was added. As negative controls, cells were kept in medium without any factor. After $2 \mathrm{~h}$, medium was aspirated and cells were washed with phosphate buffered saline (PBS) to ensure complete removal of the factors.

An initial screen at the mRNA level was performed at $72 \mathrm{~h}$ to ensure an effect of short-term stimulation could be observed. In this initial set of experiments, cells were maintained at $37{ }^{\circ} \mathrm{C}$ and $5 \% \mathrm{CO}_{2}$ in DMEM low glucose with $10 \%$ foetal calf serum (FCS) (to prevent cell death) and $1 \%$ penicillin/streptomycin. A second set of experiments to investigate mRNA expression and secreted protein analysis, was also carried out. In the second set of experiments, cells were cultured for $48 \mathrm{~h}$ at $37^{\circ} \mathrm{C}$ and $5 \%$ $\mathrm{CO}_{2}$ in serum-free DMEM low glucose with $1 \%$ penicillin/
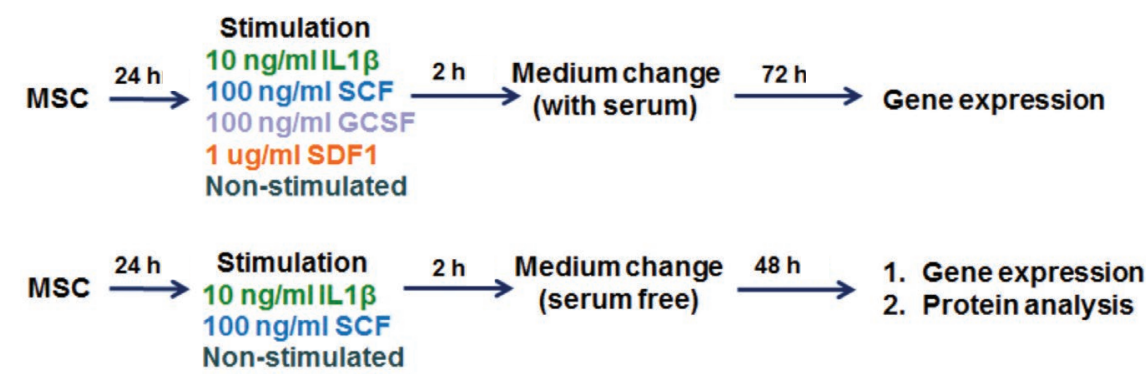

Fig. 1. Experimental outline. 
streptomycin to reduce protein contamination from the serum in the secretome analysis (Fig.1).

\section{RNA extraction and reverse transcription}

RNA was extracted from cells with TRI reagent followed by on-column method (Qiagen, Hombrechtikon, Switzerland) as previously described (Czekanska et al., 2013). After the extraction, RNA samples were treated with RQ1 (RNAQualified) RNase-free DNase to ensure very high quality of RNA samples. Manufacturers' protocol was followed for DNase digestion. After the reaction, the enzyme and buffer components were removed with on-column RNA Clean-Up protocol (Qiagen). Reverse transcription of samples designated for the gene expression analysis with $\mathrm{RT}^{2}$ PCRArrays was performed using $\mathrm{RT}^{2}$ First Strand Kit according to the supplied instructions. For the gene expression analysis with Real-Time PCR, complementary DNA(cDNA) was transcribed from $0.5 \mu \mathrm{g}$ total RNA using the TaqMan Reverse Transcription kit.

\section{Cytokine gene expression analysis with $R^{2}$ PCRArrays}

The RT ${ }^{2}$ Profiler ${ }^{\mathrm{TM}}$ PCR Array system containing primer assays for 84 cytokine genes of interest was applied to analyse the expression of human cytokine genes. Reactions were prepared according to the manufacturer's instructions and run on StepOne Plus cycler (Applied Biosystems/Life Technologies, Foster City, CA, USA). Each plate was incubated for $10 \mathrm{~min}$ at $95^{\circ} \mathrm{C}$ and followed by 40 cycles of PCR reaction at $95{ }^{\circ} \mathrm{C}$ for $15 \mathrm{~s}$ and $60{ }^{\circ} \mathrm{C}$ for $1 \mathrm{~min}$. To confirm the absence of nonspecific amplification a dissociation curve was generated $\left(60-95{ }^{\circ} \mathrm{C}\right.$ for $\left.20 \mathrm{~min}\right)$. After all reactions, the same threshold was set across all PCR array runs. Data was analysed with the SABiosciences PCR Array Analysis Web-based software. The mean of two housekeeping genes, $\beta$-2-microglobulin and RPL13A, was used for calculating $\Delta \mathrm{C}_{\mathrm{T}}$. Gene expression was calculated using the $2^{-\triangle \Delta C T}$ method.

\section{Real-time PCR}

Gene expression was analysed with TaqMan probes (Table. 2). RealTime-PCR was performed using StepOne Plus Real-Time PCR System (Applied Biosystems). The reactions were run for $2 \mathrm{~min}$ at $56{ }^{\circ} \mathrm{C}, 10 \mathrm{~min}$ at $95{ }^{\circ} \mathrm{C}$, followed by 40 cycles of $15 \mathrm{~s}$ at $95{ }^{\circ} \mathrm{C}$ and $1 \mathrm{~min}$ at $60^{\circ} \mathrm{C}$. Expression of the genes of interest in samples was normalised to RPL13a. Analysis of relative gene expression was performed using $2^{-\Delta \Delta \mathrm{CT}}$ method. Expression levels of genes in MSCs stimulated with IL1 $\beta$ or SCF were made relative to the gene expression in unstimulated MSCs.

\section{Conditioned medium (CM) collection and protein analysis}

Medium conditioned by stimulated or unstimulated cells was collected and centrifuged at $1000 \mathrm{x} g$ at $4{ }^{\circ} \mathrm{C}$ for $20 \mathrm{~min}$. Supernatant was transferred into fresh tubes and stored until required at $-20{ }^{\circ} \mathrm{C}$. The analysis of secrotome was performed using RayBio ${ }^{\circledR}$ Human Cytokine Antibody Array G-series 2000 (RayBiotech, Norcross, GA, USA), which enables detection and semi-quantitative evaluation of 174 cytokine proteins. Preparation of all reagents and procedure was followed according to the supplied instructions. Proteins present in the CM were detected using GenePix 4000B Microarray Scanner (Axon Instruments; Molecular Devices, Sunnyvale, CA, USA). The results were expressed as $n$-fold signal intensity compared to positive control samples. For further analysis, these results were normalised to the number of cells harvested after the collection of CM from cells stimulated or unstimulated cells. To estimate differences in protein synthesis between groups, $n$-fold change was calculated between stimulated groups and control.

\section{Statistical analysis}

The data included for statistical analysis are presented as means \pm standard error (SE) of independent experiments. All obtained data underwent statistical analysis using SPSS

Table 2. Primers and probes were purchased from Applied Biosystems, except for Runx2, where the primers and probe were purchased from Mycrosynth, $\mathrm{CH}$.

\begin{tabular}{|l|l|}
\hline Gene & Order Code or Sequence \\
\hline RPL13a (Housekeeping gene) & Hs_01926559_g1 \\
\hline Alkaline Phosphatase & Hs_00758162_m1 \\
\hline Sox9 & Hs_00165814_m1 \\
\hline Interleukin-6 (IL-6) & Hs_00985639_m1 \\
\hline Interleukin-8 (IL-8) & Hs_00174103_m1 \\
\hline Interleukin-10 (IL-10) & Hs_00961622_m1 \\
\hline TNF $\alpha$ & Hs_01113624_g1 \\
\hline Wnt3a & Hs_00263977_m1 \\
\hline Wnt4 & Hs_00229142_m1 \\
\hline Wnt5a & Hs_00998537_m1 \\
\hline Wnt7b & Hs_00536497_m1 \\
\hline$\beta$-catenin & Hs_00170025_m1 \\
\hline Runx2 & $\begin{array}{l}\text { forward: AGCAAGGTTCAACGATCTGAGAT } \\
\text { reverse: TTTGTGAAGACGGTTATGGTCAA } \\
\text { probe: TGAAACTCTTGCCTCGTCCACTCCG }\end{array}$ \\
\hline
\end{tabular}



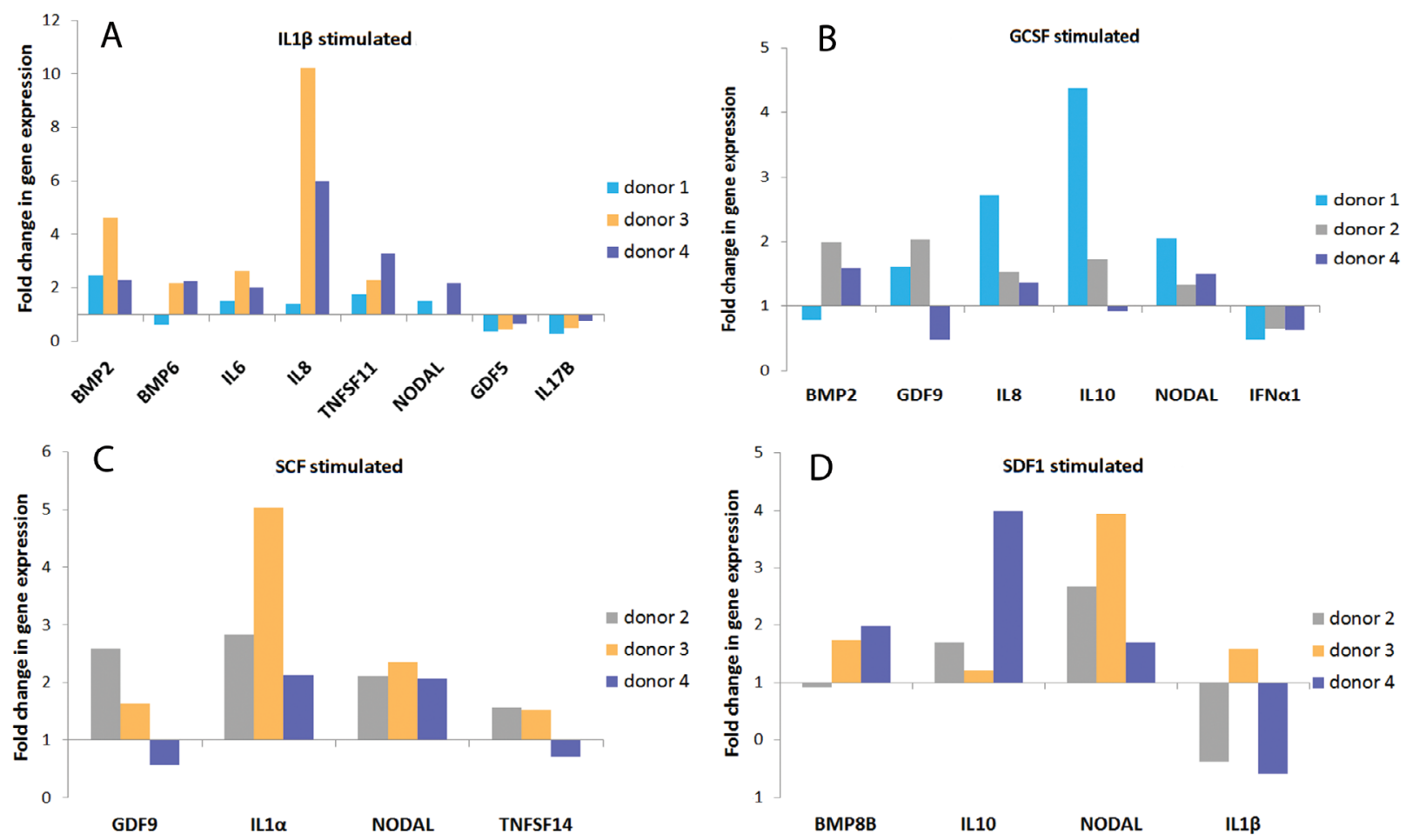

Fig. 2. Diagrams showing the mRNA levels of cytokines in MSC cells stimulated by IL1 $\beta$ (A), GCSF (B), SCF (C) and SDF1 (D). Cells in monolayer were stimulated with the specific factor for $2 \mathrm{~h}$. Cells without any stimulation were included as controls for assessing regulatory effects of stimulation. Gene expression level in stimulated cells was expressed relative to control samples.

21.0 (Chicago, IL, USA) software package. Statistical significance at $p<0.05$ of gene expression in stimulated cells compared to unstimulated cells was determined with Mann-Whitney U test.

\section{Results}

Influence of stimulation on cytokine gene expression by MSCs in serum-containing medium

The cytokine and growth factor gene expression analysis in MSC revealed donor dependent response to the stimulation. Yet, consistent effects at the mRNA level $72 \mathrm{~h}$ after stimulation were detected. Response to the treatment was assessed as positive if up- or downregulation of a gene occurred in cells obtained from at least 2 out of 3 donors compared to untreated controls $(n=3$ for each factor and control). Due to differential sensitivity of cells from different donors to the stimulation, results are presented for each individual donor.

A $2 \mathrm{~h}$ stimulation of cells with $10 \mathrm{ng} / \mathrm{mL}$ IL $1 \beta$ resulted in the upregulation of a wide range of cytokine genes $72 \mathrm{~h}$ later. The highest upregulation was detected for BMP2, IL8, TNFSF11 and IL6 in cells from all three donors. BMP6 and NODAL were upregulated in 2 out of 3 donors. In addition, 2 cytokines, GDF5 and IL17B were downregulated in all three donors in response to the treatment (Fig. 2A).

GCSF stimulation resulted in a pronounced upregulation of mRNA expression of 5 cytokines (BMP2, GDF9,
IL10, (2/3 donors) IL8, NODAL (3/3 donors)) and downregulation of one cytokine (INFA1). Cells from all three donors consistently downregulated INFA1 gene expression compared to unstimulated cells (Fig. 2B).

MSC stimulation with $100 \mathrm{ng} / \mathrm{mL} \mathrm{SCF}$ resulted in high upregulation of IL1A and NODAL in all donors. As seen with GCSF stimulation, cells from donor 4 stimulated with SCF showed the lowest level of response. In addition, two of the donors ( 1 and 2) positively responded to stimulation by increasing the expression of GDF9 and TNFSF11 compared to unstimulated cells. Interestingly, donor 4, who showed the lowest upregulation in IL1A and NODAL expression out of all donors, showed an opposite response regarding GDF9 and TNFSF11 in comparison to the two other donors (Fig. 2C).

Transient stimulation with SDF1 modified the expression of 4 genes after $72 \mathrm{~h}$. A high upregulation of NODAL gene expression was detected in response to SDF1 treatment in all three donors. Additionally, stimulation had positive effects on two other cytokines, BMP8B and IL10, whereas IL1 $\beta$ was strongly downregulated in 2 out of 3 donors (Fig. 2D). The positive response to SDF1 stimulation in IL1 $\beta$ regulation was detected in cells from donor 3 .

\section{Influence of a $2 \mathrm{~h}$ IL1 $\beta$ and SCF stimulation on cytokine gene expression by MSC in serum-free medium cell culture}

In the time between stimulating the cells with either IL1 $\beta$ $(n=5)$ or SCF $(n=3)$ and mRNA sample collection, 

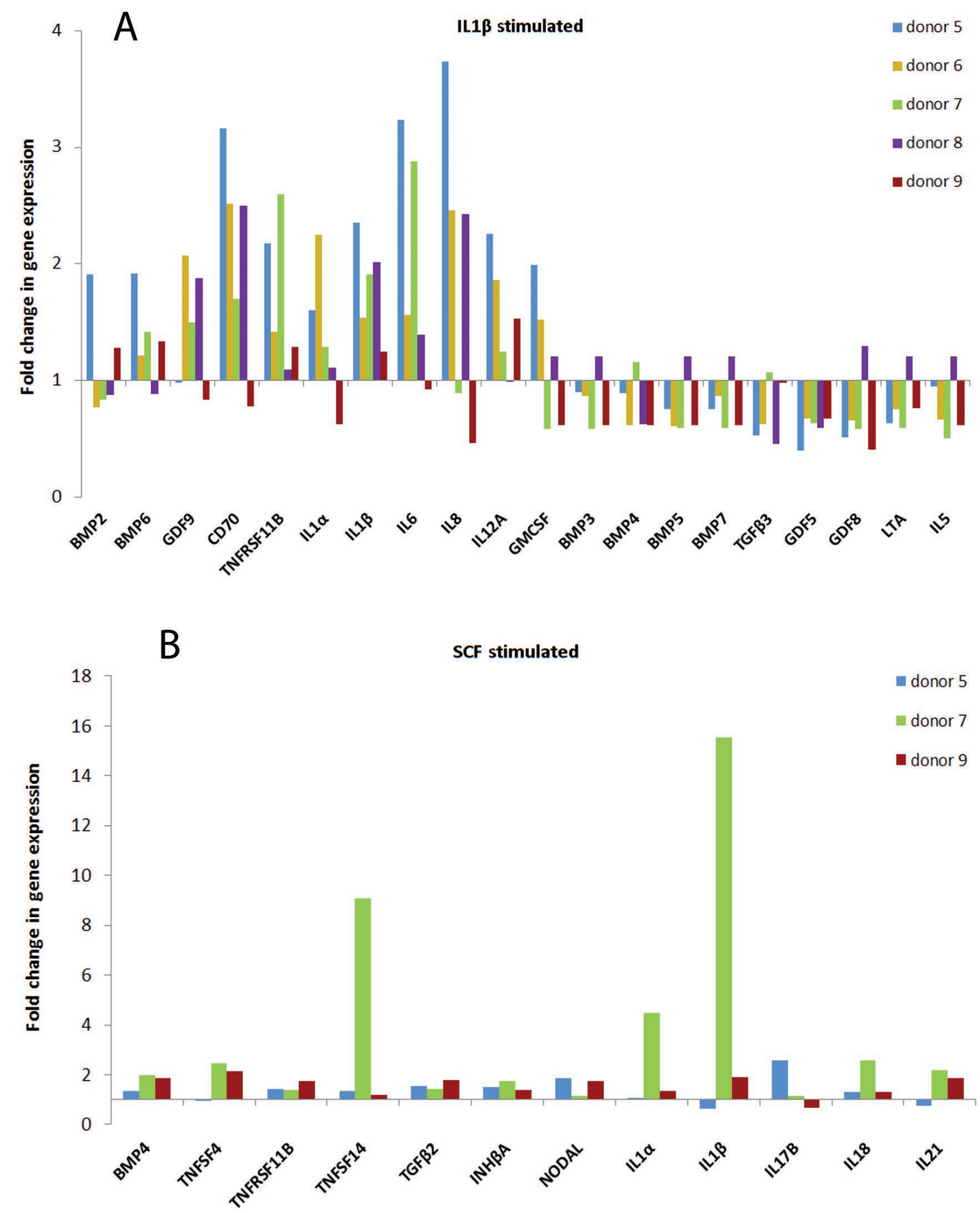

Fig. 3. (A) mRNA levels of cytokines in MSC cells stimulated with IL1 $\beta$. Cells in monolayer were stimulated with $10 \mathrm{ng} / \mathrm{mL}$ IL1 $\beta$ for $2 \mathrm{~h}$. Cells without any stimulation were included as controls for assessing regulatory effects of stimulation. The gene expression level from stimulated cells was made relative to control samples. (B) mRNA levels of cytokines in MSC cells stimulated with SCF. Cells in monolayer were stimulated with $100 \mathrm{ng} / \mathrm{mL} \mathrm{SCF}$ for $2 \mathrm{~h}$. Cells without any stimulation were included as controls for assessing regulatory effects of stimulation. The gene expression level from stimulated cells was made relative to control samples. 

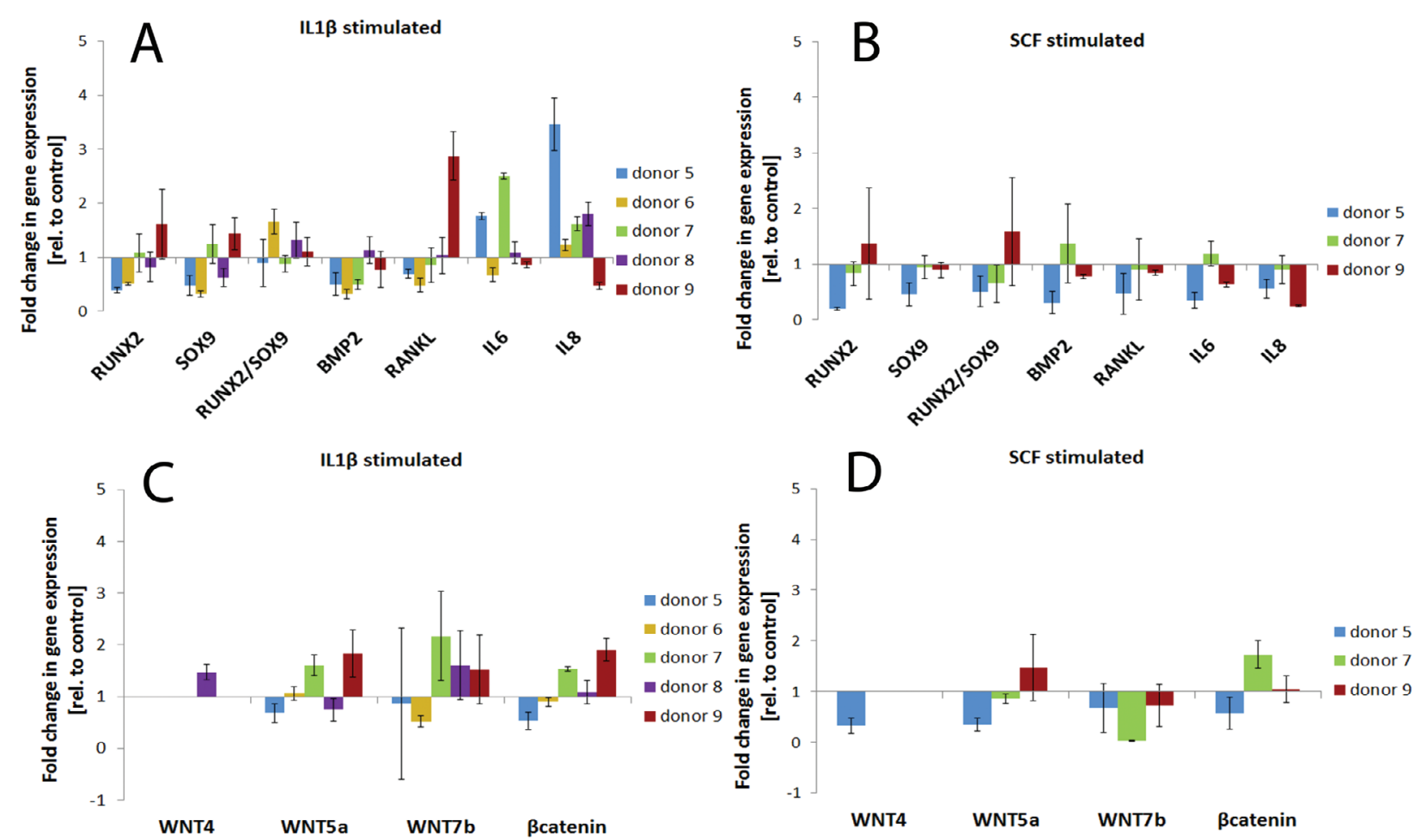

Fig. 4. Diagrams show the fold change gene expression in relative to control from each donor with the standard deviation, quantified by real-time PCR $48 \mathrm{~h}$ after the stimulation of MSC with IL1 $\beta$ or SCF for 2 h. (A, C) Cells stimulated with IL1 $\beta$; (B, D) Cells stimulated with SCF. Cells from 5 and 3 donors were stimulated with IL1 $\beta$ or $\mathrm{SCF}$, respectively.

some of the samples were maintained in serum-free DMEM medium. Forty eight hours after the stimulation with IL1 $\beta$, mRNA expression of 20 cytokine genes were similarly regulated in at least of 3 out of 5 donors (Fig. 3A). Stimulation of MSCs with IL1 $\beta$ resulted in an upregulation of TNFRSF11B and IL1 $\beta$ and a downregulation of GDF5 gene expression in all 5 donors (Fig. 3A). An increased mRNA expression in stimulated cells was detected for: BMP6, CD70, IL1 $\alpha$, IL6, IL8 and IL12A in 4 out of 5 donors. On the other hand, various BMP-family members (BMP3, 4, 5 and 7), TGF 33, GDF8, LTA and IL5 were downregulated in 4 donors. A positive response in GDF9 and GMCSF gene regulation was detected in cells from 3 donors. Similarly, 3 out of 5 donors downregulated BMP2 gene expression after $2 \mathrm{~h}$ stimulation with IL1 $\beta$ (Fig. 3A).

MSC from 3 donors were treated for $2 \mathrm{~h}$ with SCF. As a result, 12 cytokine genes showed response to the stimulation in at least 2 donors (Fig. 3B.). Eight of these genes were upregulated in cells from all 3 donors. More specifically, the mRNA level in stimulated cells relative to unstimulated cells was higher for BMP4, TNFRSF11B, TNFSF14, TGF $\beta 2$, INHBA, NODAL, IL1 $\alpha$ and IL18. Due to an opposite response in regulation of TNFSF4, IL1 $\beta$, IL17 $\beta$ and IL21 in cells from donor 5 or 9 (compared to other donors), these genes were upregulated only in 2 out of 3 donors (Fig. 3B).

It has to be highlighted that overall the magnitude of the response was lower compared to the effect of IL $1 \beta$ on cytokine gene regulation. Approximately a 2 -fold increase in gene regulation, relative to unstimulated controls, was detected after SCF stimulation. As an exception, cells from donor 7 were the most sensitive to SCF stimulation, which was marked by the highest increase of TNFSF14, IL1 $\alpha$, IL1 $\beta$, IL18, IL21 and TNFSF4 mRNA level among all 3 donors (Fig. 3B).

\section{Regulation of the expression of osteogenic and Wnt signalling genes in MSCs stimulated with IL1 $\beta$ and SCF}

The gene expression analysis of IL6, IL8, BMP2, RANKL was conducted to confirm the results obtained from $\mathrm{RT}^{2}$ PCR array analysis (Fig. 4). Additionally, the components of the canonical and non-canonical Wnt signalling pathways, and osteogenic markers (Sox9, Runx2) were assessed at the mRNA level (Fig. 4). Similar to results from the cytokine gene expression arrays, the gene regulation in response to the stimulation was donor dependent. Out of 5 donors, cells from donor 9 showed the opposite response to IL1 $\beta$ treatment than cells from other donors included in the analysis (Fig. 4A,C). Cells from the 4 other donors (donors 5-8) showed a similar trend in the response to IL1 $\beta$. Hence, donor 9, as an outlier, was excluded from the statistical analysis. For stimulation with SCF, cells from all donors were included for the analysis of any significant differences in response to the stimulation.

IL1 $\beta$ stimulation significantly downregulated mRNA expression of bone markers, including Runx2 $(p=0.02)$, $\operatorname{Sox} 9(p=0.02), \operatorname{BMP} 2(p=0.01)$ and $\operatorname{RANKL}(p=0.01)$ 

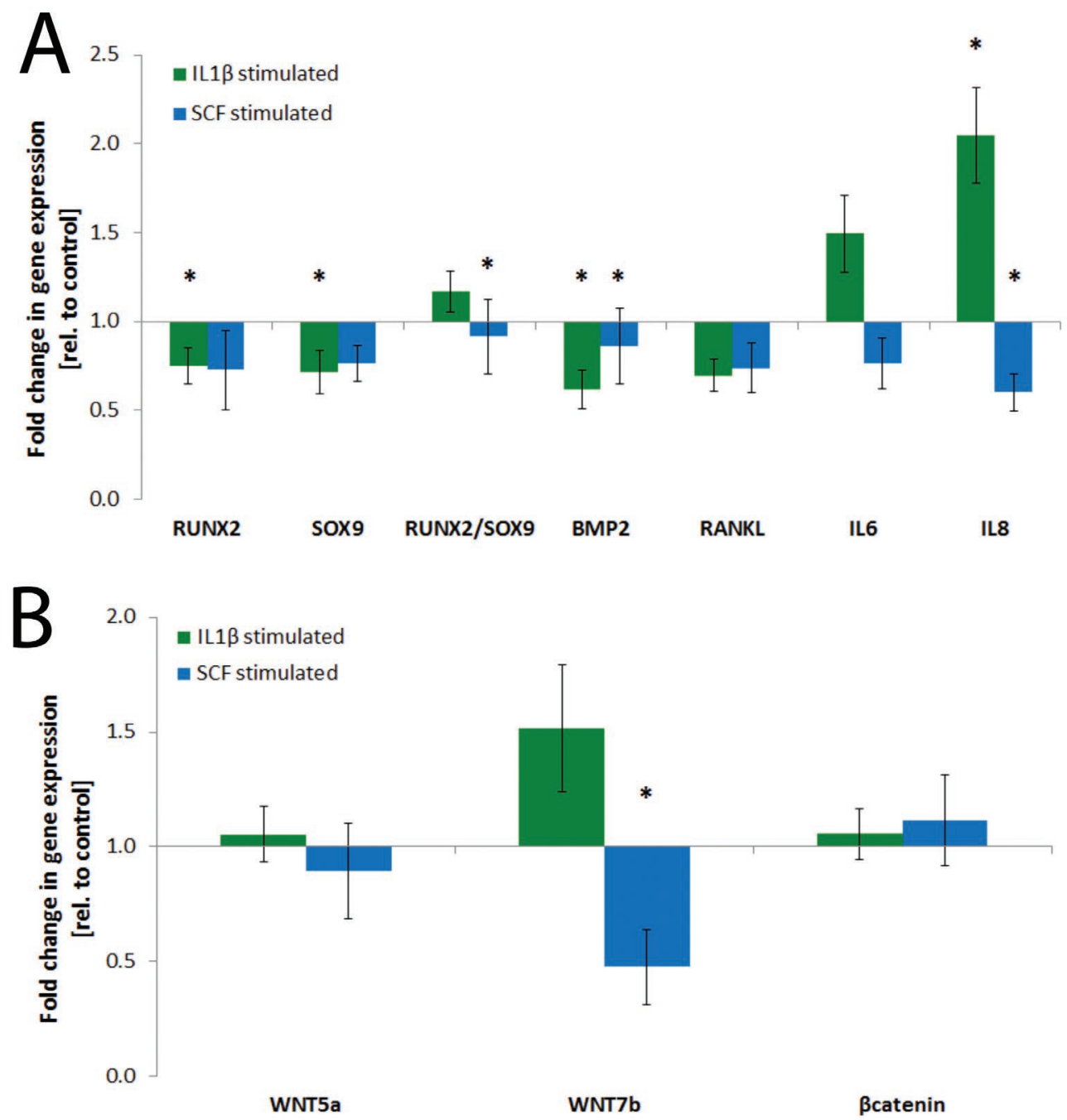

Fig. 5. Diagrams show the mean fold change gene expression relative to control with the standard error of the mean, quantified by real-time PCR $48 \mathrm{~h}$ after the stimulation of MSC with IL1 $\beta$ or SCF for 2 h. (A) Expression of genes: Runx2, Sox9, Runx2/Sox9, BMP2, RANKL, IL6, IL8; (B) Expression of Wnt5a, Wnt7b and $\beta$-catenin. Gene expression was normalised to RPL13a and made relative to expression of genes in unstimulated cells. Statistical significance at $p<0.05(*)$ of genes compared to unstimulated cells was determined with Mann-Whitney $\mathrm{U}$ test.

(Fig. 5A). IL1 $\beta$ stimulation had no effect on the overall Runx2/Sox 9 ratio compared to unstimulated cells $(p=0.468)$. Treatment with IL1 $\beta$ increased the expression of IL6 and IL8. Yet, this increase was significant only for IL8 $(p<0.001)$. Stimulation with SCF showed a negative effect on the regulation of Runx2, Sox9, BMP2, RANKL, IL6 and IL8 genes (Figs. 4B,5A). This decreased expression reached significance for Sox $9(p=0.05)$, RANKL $(p=0.004)$ and IL8 $(p=0.004)$ (Fig. 5A).

It was only possible to detect Wnt 4 expression in cells from donor 8 and in donor 5 after the stimulation with IL1 $\beta$ and SCF (Fig. 4C,D). Moreover, mRNA expression of Wnt3 was not detected in any donor. Although, there were no significant differences in gene expression of Wnt5a $(p=0.748), \mathrm{Wnt7b}(p=0.3)$ or $\beta$-catenin $(p=0.748)$ between stimulated with IL1 $\beta$ and unstimulated cells, there was a trend of higher expression of Wnt7b compared to control (Fig. 5B). Stimulation of MSCs with SCF had no influence on the mRNA expression of Wnt5a $(p=0.256)$ or $\beta$-catenin $(p=0.73)$, whereas it significantly decreased Wnt7b expression $(p=0.008)$ compared to control (Fig. 5B).

\section{Influence of stimulation on cytokine protein secretion} by MSCs in serum-free medium cell culture

The regulation of 174 cytokine proteins in response to IL $1 \beta$ or SCF stimulation was highly donor dependent, which prevented presentation of averaged results. Nevertheless, it was possible to analyse results in a manner similar to the gene expression results.

The initial analysis of the fluorescence intensity of the medium samples collected from unstimulated cells revealed the secretion of 139 proteins by cells from donor 5, 152 from donor 6 and 9, 154 from donor 7 and 153 from donor 8 (Table 3 ). For both treatments, the expression of 

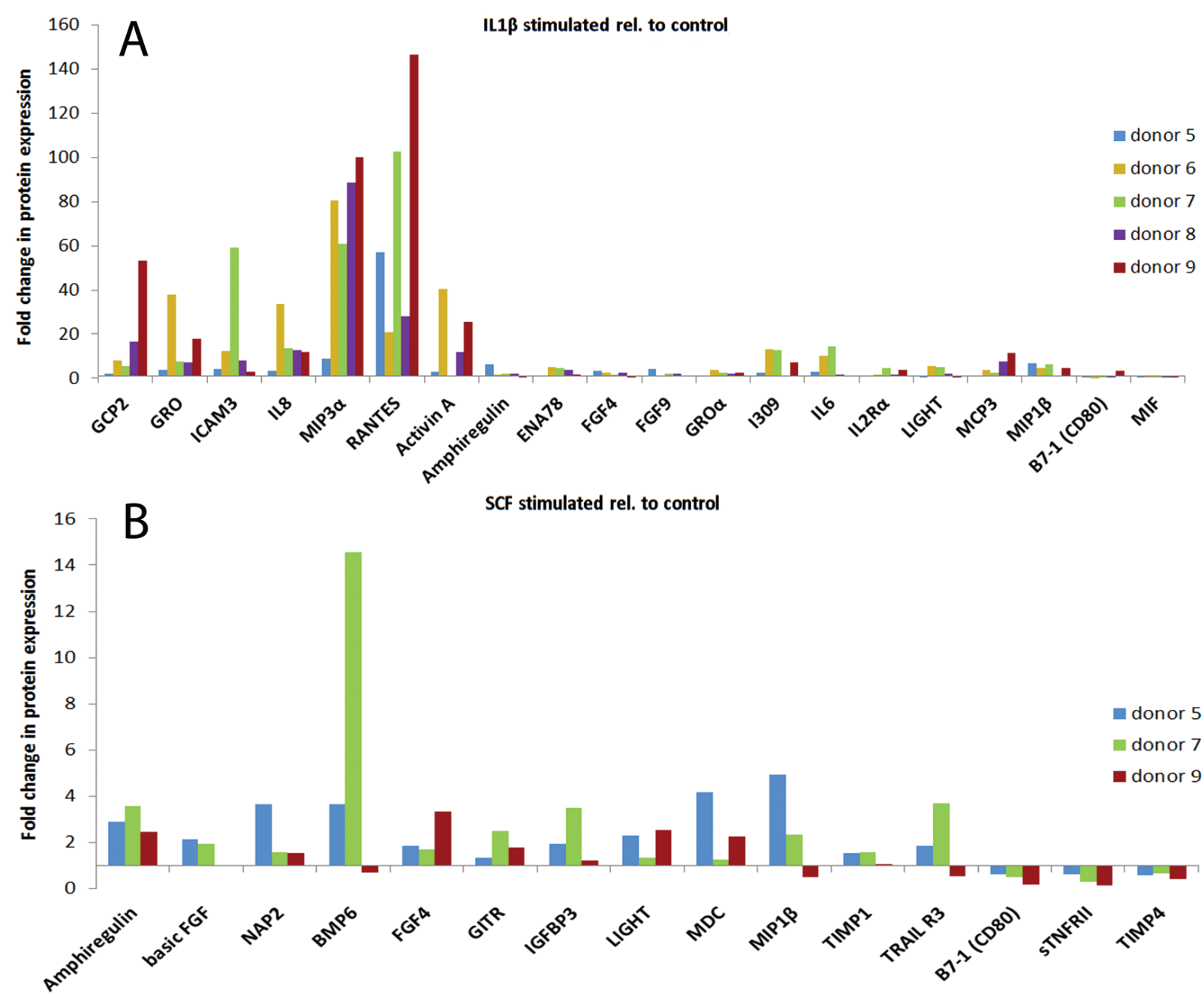

Fig. 6. (A) Protein levels of cytokines in medium conditioned by MSCs stimulated with IL1 $\beta$. Monolayer cells were stimulated for $2 \mathrm{~h}$ with $10 \mathrm{ng} / \mathrm{mL}$ IL1 $\beta$. After stimulation, cells were washed with DMEM and maintained in DMEM with $1 \%$ penicillin/streptomycin for $48 \mathrm{~h}$. After that time conditioned medium was collected for the analysis of secreted proteins. (B) Protein levels of cytokines in medium conditioned by MSCs stimulated with SCF. Monolayer cells were stimulated for $2 \mathrm{~h}$ with $100 \mathrm{ng} / \mathrm{mL}$ SCF. After stimulation, cells were washed with DMEM and maintained in DMEM with $1 \%$ penicillin/streptomycin for $48 \mathrm{~h}$. After that time conditioned medium was collected for the protein secretion analysis.

proteins in conditioned medium (CM) was made relative to protein secretion into medium by unstimulated (control) cells. In case of IL1 $\beta$ stimulation, if cells from at least 3 out of 5 donors showed similar regulation of proteins, the effect of stimulation was assessed as positive. Similar conclusions were made for SCF stimulation, when cells from at least 2 out of 3 donors responded to stimulation in similar fashion. All regulated cytokine proteins were grouped depending on their function (Fig. 7), showing that the $2 \mathrm{~h}$ stimulation with IL1 $\beta$ mostly influenced the secretion of proteins involved in chemotaxis, inflammation, angiogenesis and bone formation. The stimulation with SCF affected mitogenic, ECM and differentiation markers.

Stimulation with IL1 $\beta$ influenced protein synthesis and secretion in MSC cells. Specifically, 18 out of 174 analysed proteins were upregulated in the conditioned medium collected at $48 \mathrm{~h}$ from cells stimulated with IL1 $\beta$ and compared to conditioned medium from unstimulated cells (Fig. 6A). A lower secretion of 2 proteins, B7-1 and MIF, was observed in response to IL1 $\beta$ stimulation. Out of the upregulated 18 proteins, 9 of them, GCP2, GRO, ICAM3, IL8, MIP3 $\alpha$, RANTES, I309, IL6, IL2R $\alpha$ and MCP3, were upregulated in cells isolated from all 5 donors. This strongly indicates the regulatory role of IL $1 \beta$ on these cytokines. An increased expression of a further 9 proteins, including Activin A, Amphiregulin, ENA78, FGF4, FGF9, GRO $\alpha$ and LIGHT, was detected $48 \mathrm{~h}$ after IL1 $\beta$ stimulation in at least 3 of 5 donors (Fig. 6A).

Among 174 proteins analysed from medium conditioned by MSCs stimulated with SCF, secretion of 15 of them were specifically regulated in response to the stimulation (Fig.6B). In relation to results from controls, SCF stimulation showed a negative effect on B7-1, sTNFRII and TIMP4 protein secretion in cells from all 3 donors. On the other hand, all donors showed a positive response to SCF stimulation by increased secretion of Amphiregulin, NAP2, 


\begin{tabular}{l|l}
\hline \multicolumn{1}{c|}{ Function } & \multicolumn{1}{c}{ Cytokine } \\
\hline Chemotactic & $\begin{array}{l}\text { GCP2, RANTES, MIP1 } \beta, \text { MIP3 } \alpha, \text { IL2R } \alpha, \text { ENA78, } \\
\text { IL8, MDC, B7-1 }\end{array}$ \\
\hline Mitogenic & $\begin{array}{l}\text { Amphiregulin, NAP2, IGFBP3, basic FGF, FGF4, } \\
\text { sTNFRII }\end{array}$ \\
\hline Proinflammatory & GRO, I309, GRO $\alpha$, ICAM3 \\
\hline Immunoregulation & MIF, IL8, IL2R $\alpha$, GITR, LIGHT \\
\hline Bone formation & FGF4, Amphiregulin, Activin A, IL6, IGFBP3 \\
\hline Angiogenesis & GCP2, FGF9, IL6, IL8, RANTES, ENA78 (indirectly) \\
\hline Chondrogenesis & BMP6 \\
\hline ECM regulation & TIMP1, TIMP4 \\
\hline
\end{tabular}

Fig. 7. Functional grouping of cytokines regulated by $2 \mathrm{~h}$ stimulation of bone marrow derived MSC cells with $10 \mathrm{ng} /$ $\mathrm{mL}$ IL $1 \beta$ or $100 \mathrm{ng} / \mathrm{mL}$ SCF. Colours indicate response to the stimulation: dark green - upregulation after stimulation with $10 \mathrm{ng} / \mathrm{mL}$ IL1 $\beta$, light green - downregulation after $10 \mathrm{ng} / \mathrm{mL}$ IL1 $\beta$ stimulation, dark blue - upregulation after stimulation with $100 \mathrm{ng} / \mathrm{mL} \mathrm{SCF}$, light blue - downregulation, dark brown - upregulation by $10 \mathrm{ng} / \mathrm{mL}$ IL1 $\beta$ and $100 \mathrm{ng} / \mathrm{mL}$ SCF, light brown - downregulation by $10 \mathrm{ng} / \mathrm{mL}$ IL1 $\beta$ and $100 \mathrm{ng} / \mathrm{mL} \mathrm{SCF}$. B7-1 = CD80 - cluster of differentiation 80; basic FGF - basic fibroblast growth factor; BMP4 - bone morphogenic protein 4; BMP6 - bone morphogenic protein 6; ENA78/CXCL5 - epithelial-derived neutrophil-activating peptide 78; FGF4 - fibroblast growth factor 4; GCP2 - granulocyte chemotactic protein; GITR/TNFRSF18 - glucocorticoid induced tumour necrosis factor receptor family related gene; GRO - growth-related oncogene; GRO $\alpha$ - growth-related oncogene alpha; I309 = CCL1 - chemokine (C-C motif) ligand 1; ICAM3/CD50 - intercellular adhesion molecule 3; IGFBP3 - insulin-like growth factor binding protein-3; IL2R $\alpha$ - interleukin 2 receptor alpha; IL1 $\beta$ - interleukin 1 beta; IL6 - interleukin 6; IL8 - interleukin 8; LIGHT = TNFSF14 - tumour necrosis factor ligand superfamily member 14; MIF - Macrophage migration inhibitory factor; MIP1 $\beta$ /CCL4 - Macrophage inflammatory protein-1 beta; MIP3 $\alpha$ Macrophage inflammatory protein-3alpha; NAP2 - neutrophil-activating protein-2; RANTES/CCL5 - regulated on activation, normal T cell expressed and secreted; SCF - stem cell factor; sTNFRII - soluble tumour necrosis factor receptor type II; TIMP1 - tissue inhibitor of metalloproteinase-1; TIMP4 - tissue inhibitor of metalloproteinase-4.

FGF4, GITR, IGFBP3, LIGHT, MDC, TIMP1. Basic FGF, BMP6, MIP1beta and TRAILR3 were upregulated in 2 out of 3 donors, with donor 9 being the exception (Fig. 6B).

\section{Discussion}

Immediately after tissue injury or trauma an inflammation response occurs, during which various molecules are released. These factors influence the behaviour and potential of cells involved in the regenerative process. Here, we investigated the longer term effects of a transient $2 \mathrm{~h}$ stimulation, with cytokines present during inflammation, on MSC gene expression and secretome. Few studies have been performed using a transient stimulation of MSCs in order to modify their phenotype. The short-term stimulation of human adipose derived stem cells with BMP2, to enhance osteogenic differentiation, showed superior results in a $3 \mathrm{D}$ biphasic calcium phosphate scaffold compared to a monolayer culture (Overman et al., 2013a). This occurred after a 15 min stimulation, suggesting it may be possible to reduce the $2 \mathrm{~h}$ used during this study. Moreover, the gene expression of trophic factors was differentially regulated in cells cultured in scaffolds compared to monolayer (Overman et al., 2013b).

\section{mRNA analysis after $72 \mathrm{~h}$ of serum containing culture}

In the initial set of experiments in serum-containing medium, PCR array results showed that even after only $2 \mathrm{~h}$ stimulation of cells with each factor, a pronounced cell response was still detectable $72 \mathrm{~h}$ after treatment. This would be the critical engraftment time in a clinical setting. Stimulation with IL1 $\beta$ regulated the mRNA expression of the highest number of cytokine genes, emphasising its multifunctional role. Grouping the cytokines based on function can give some indication as to the overall effect that might be obtained. However, due to the complex interactions between the different cytokines, this would need to be further investigated in vivo to establish actual clinical benefit. These studies are currently planned. Cytokines, which responded to the IL1 $\beta$ treatment, take part in bone formation (BMP2, BMP6), angiogenesis (IL6, IL8), osteoclastogenesis (TNFSF11), development (NODAL), chondrogenesis (GDF5) and immunomodulation (IL17B). Specifically, only IL1 $\beta$ regulated the expression of BMP6, IL6, TNSFF11 and GDF5. SCF stimulation showed no effect on the gene expression of cytokines implicated in angiogenesis or bone formation. However, it upregulated genes involved in chondrogenesis (GDF9), immunomodulation (IL1A) and 
Table 3. A-B. Cytokine protein levels secreted by unstimulated MSCs analysed using RayBio Cytokine Array G-Series. Cells in monolayer were cultured for $48 \mathrm{~h}$ in serum-free medium. Protein level secreted by unstimulated MSCs (control) determined by the fluorescence signal intensity: $n . d$. (= not detected) - for the signal intensity up to 10 ; low - signal intensity of 10-1,000; medium - signal intensity of 1,001-10,000; high - signal intensity above 10,000.

A

\begin{tabular}{|c|c|c|c|c|c|}
\hline Protein & donor 5 & donor 6 & doonor 7 & donor 8 & donor 9 \\
\hline Angiogenin & medium & high & high & high & high \\
\hline BDNF & low & low & low & low & low \\
\hline BLC & low & low & low & low & n.d. \\
\hline BMP-4 & low & n.d. & n.d. & n.d. & n.d. \\
\hline BMP-6 & n.d. & n.d. & n.d. & n.d. & low \\
\hline CK beta 8-1 & low & low & low & low & n.d. \\
\hline CNTF & low & low & low & low & low \\
\hline EGF & n.d. & n.d. & n.d. & n.d. & low \\
\hline Eotaxin & low & n.d. & n.d. & low & n.d. \\
\hline Eotaxin-2 & n.d. & n.d. & n.d. & n.d. & n.d. \\
\hline Eotaxin-3 & low & low & low & low & low \\
\hline FGF-6 & low & low & low & low & low \\
\hline FGF-7 & low & low & low & low & low \\
\hline Flt-3 Ligand & low & low & low & low & low \\
\hline Fractalkine & low & n.d. & n.d. & n.d. & n.d. \\
\hline GCP-2 & low & low & n.d. & low & n.d. \\
\hline GDNF & low & low & low & low & n.d. \\
\hline GM-CSF & low & low & low & low & low \\
\hline I-309 & low & n.d. & n.d. & low & n.d. \\
\hline IFN-gamma & low & low & low & low & low \\
\hline IGFBP-1 & low & low & low & low & n.d. \\
\hline IGFBP-2 & low & low & low & low & low \\
\hline IGFBP-4 & low & low & low & low & n.d. \\
\hline IGF-I & n.d. & n.d. & n.d. & n.d. & n.d. \\
\hline IL-10 & low & low & low & low & low \\
\hline IL-13 & low & low & low & low & low \\
\hline IL-15 & low & low & low & low & low \\
\hline IL-16 & n.d. & n.d. & n.d. & n.d. & n.d. \\
\hline IL-1alpha & low & low & low & low & low \\
\hline IL-1beta & low & low & low & low & low \\
\hline IL-1ra & low & low & low & low & low \\
\hline IL-2 & low & low & low & low & low \\
\hline IL-3 & low & low & low & low & low \\
\hline IL-4 & n.d. & n.d. & n.d. & n.d. & n.d. \\
\hline IL-5 & low & low & low & low & low \\
\hline IL-6 & high & medium & medium & high & high \\
\hline IL-7 & low & low & low & low & low \\
\hline Leptin & low & low & low & low & low \\
\hline LIGHT & low & n.d. & n.d. & low & n.d. \\
\hline МCP-1 & high & high & high & high & high \\
\hline МCP-2 & low & low & low & low & low \\
\hline МCP-3 & low & low & low & low & low \\
\hline МСР-4 & low & low & low & low & low \\
\hline M-CSF & low & low & low & low & low \\
\hline MDC & low & n.d. & n.d. & n.d. & n.d. \\
\hline MIG & low & low & low & low & low \\
\hline MIP-1-delta & n.d. & n.d. & n.d. & n.d. & n.d. \\
\hline MIP-3-alpha & low & n.d. & n.d. & n.d. & n.d. \\
\hline NAP-2 & low & low & low & low & n.d. \\
\hline NT-3 & low & low & low & low & n.d. \\
\hline PARC & low & low & low & low & low \\
\hline PDGF-BB & low & low & low & low & low \\
\hline RANTES & low & low & low & low & low \\
\hline SCF & low & low & low & low & low \\
\hline SDF-1 & low & low & low & low & low \\
\hline TARC & low & low & low & low & n.d. \\
\hline TGF-beta 1 & low & low & low & low & low \\
\hline TGF-beta 3 & n.d. & n.d. & n.d. & n.d. & n.d. \\
\hline TNF-alpha & low & low & low & low & low \\
\hline TNF-beta & low & low & low & low & low \\
\hline
\end{tabular}

B

\begin{tabular}{|c|c|c|c|c|c|}
\hline Protein & donor 5 & donor 6 & doonor 7 & donor 8 & donor 9 \\
\hline Acrp30 & low & low & low & low & low \\
\hline AgRP & low & low & low & low & low \\
\hline Angiopoietin-2 & medium & low & low & low & low \\
\hline Amphiregulin & n.d. & low & low & low & low \\
\hline Axl & n.d. & low & low & low & low \\
\hline bFGF & n.d. & low & low & low & low \\
\hline b-NGF & n.d. & low & low & low & low \\
\hline BTC & low & low & low & low & low \\
\hline CCL-28 & low & low & low & low & low \\
\hline CTACK & low & low & low & low & low \\
\hline Dtk & n.d. & low & low & low & low \\
\hline EGF-R & low & low & low & low & low \\
\hline ENA-78 & n.d. & low & low & low & low \\
\hline Fas/TNFRSF6 & low & low & low & low & low \\
\hline FGF-4 & n.d. & low & low & low & low \\
\hline FGF-9 & n.d. & low & low & low & low \\
\hline GCSF & low & low & low & low & low \\
\hline GITR-Ligand & low & low & low & low & low \\
\hline GITR & n.d. & low & low & low & low \\
\hline GRO & medium & medium & medium & medium & medium \\
\hline GRO-alpha & low & low & low & low & low \\
\hline HCC-4 & low & low & low & low & low \\
\hline HGF & medium & medium & n.d. & medium & high \\
\hline ICAM-1 & n.d. & low & low & low & low \\
\hline ICAM-3 & n.d. & low & n.d. & low & low \\
\hline IGFBP-3 & n.d. & low & low & low & low \\
\hline IGFBP-6 & low & low & medium & medium & medium \\
\hline IGF-I SR & medium & low & low & low & low \\
\hline IL-1 R4/ST2 & low & low & low & low & low \\
\hline IL-1 RI & low & low & low & low & low \\
\hline IL-11 & low & low & low & low & low \\
\hline IL-12 p40 & n.d. & low & low & low & low \\
\hline IL-12 p70 & n.d. & low & low & low & low \\
\hline IL-17 & low & low & low & low & low \\
\hline IL-2 Rapha & low & low & low & low & low \\
\hline IL-6 R & n.d. & low & low & low & low \\
\hline IL-8 & low & low & low & low & low \\
\hline I-TAC & low & n.d. & low & low & low \\
\hline Lymphotactin & n.d. & low & low & low & low \\
\hline MIF & medium & low & medium & low & low \\
\hline MIP-1alpha & n.d. & n.d. & low & low & low \\
\hline MIP-1beta & n.d. & low & low & low & low \\
\hline MIP-3beta & n.d. & low & low & low & low \\
\hline MSP-alpha & low & n.d. & low & low & low \\
\hline NT-4 & low & low & low & low & low \\
\hline Osteoprotegerin & high & high & high & high & high \\
\hline Oncostatin M & low & low & low & low & low \\
\hline PIGF & low & low & low & low & low \\
\hline sgp130 & low & low & low & low & low \\
\hline sTNF RII & n.d. & low & low & n.d. & low \\
\hline STNF-RI & low & low & medium & medium & medium \\
\hline TECK & n.d. & low & low & low & low \\
\hline TIMP-1 & medium & medium & medium & medium & medium \\
\hline TIMP-2 & high & high & high & high & high \\
\hline Thrombopoietin & low & low & low & low & low \\
\hline TRAIL R3 & n.d. & low & low & low & low \\
\hline TRAIL R4 & low & low & low & low & low \\
\hline uPAR & low & medium & low & low & low \\
\hline VEGF & low & low & low & low & low \\
\hline VEGF-D & n.d. & low & low & low & low \\
\hline
\end{tabular}


Table 3. C. Cytokine protein levels secreted by unstimulated MSCs analysed using RayBio Cytokine Array G-Series. Cells in monolayer were cultured for $48 \mathrm{~h}$ in serum-free medium. Protein level secreted by unstimulated MSCs (control) determined by the fluorescence signal intensity: n.d. (= not detected) - for the signal intensity up to 10 ; low - signal intensity of 10-1,000; medium - signal intensity of 1,001-10,000; high - signal intensity above 10,000.

\begin{tabular}{|c|c|c|c|c|c|}
\hline Protein & donor 5 & donor 6 & doonor 7 & donor 8 & donor 9 \\
\hline Activin A & low & low & low & low & low \\
\hline ALCAM & low & low & low & n.d. & low \\
\hline B7-1(CD80) & n.d. & low & low & n.d. & low \\
\hline BMP-5 & low & low & low & low & low \\
\hline BMP-7 & low & low & low & low & low \\
\hline Cardiotrophin-1 & low & low & low & low & low \\
\hline CD14 & low & n.d. & low & n.d. & low \\
\hline CXCL- 16 & low & low & low & low & low \\
\hline DR6 (TNFRSF21) & low & low & low & low & low \\
\hline Endoglin & low & low & low & low & low \\
\hline ErbB3 & low & low & low & low & low \\
\hline E-Selectin & low & low & low & low & low \\
\hline Fas Ligand & low & low & low & low & low \\
\hline ICAM-2 & low & low & low & low & low \\
\hline IGF-II & medium & medium & medium & medium & medium \\
\hline IL-1 R II & low & low & low & low & low \\
\hline IL-10 Rbeta & low & low & low & low & low \\
\hline IL-13 Ralpha2 & low & low & low & low & low \\
\hline IL-18 BPalpha & low & low & low & low & low \\
\hline IL-18 Rbeta & low & low & low & low & low \\
\hline IL-2 Ralpha & low & low & low & low & low \\
\hline IL-2 Rbeta & low & low & low & low & low \\
\hline IL-2 Rgamma & low & low & low & low & low \\
\hline IL-21R & low & low & low & low & low \\
\hline IL-5 Ralpha & low & low & low & low & low \\
\hline IL-9 & low & low & low & low & low \\
\hline IP-10 & low & low & low & low & low \\
\hline LAP & medium & medium & medium & medium & medium \\
\hline Leptin R & low & low & low & low & low \\
\hline LIF & low & low & low & low & low \\
\hline L-Selectin & low & low & low & low & low \\
\hline M-CSF R & low & low & low & low & low \\
\hline MMP-1 & low & low & low & low & low \\
\hline MMP-13 & low & low & low & n.d. & low \\
\hline ММР-9 & n.d. & low & low & n.d. & low \\
\hline MPIF-1 & low & low & low & low & low \\
\hline NGF R & low & low & low & low & low \\
\hline PDGF AA & low & low & low & low & low \\
\hline PDGF-AB & low & low & low & low & low \\
\hline PDGF Ralpha & low & low & low & low & low \\
\hline PDGF Rbeta & low & low & low & low & low \\
\hline PECAM-1 & n.d. & n.d. & n.d. & n.d. & low \\
\hline Prolactin & low & low & low & low & low \\
\hline SCF R & low & low & low & low & low \\
\hline SDF-1beta & low & low & low & low & low \\
\hline Siglec-5 & low & low & low & low & low \\
\hline TGF-alpha & n.d. & n.d. & n.d. & n.d. & low \\
\hline TGF beta 2 & low & low & low & low & low \\
\hline Tie-1 & low & low & low & low & low \\
\hline Tie-2 & low & low & low & low & low \\
\hline TIMP-4 & low & n.d. & low & n.d. & low \\
\hline VE-Cadherin & low & low & low & low & low \\
\hline VEGF R2 & low & low & low & low & low \\
\hline VEGF R3 & low & low & low & low & low \\
\hline
\end{tabular}

development (NODAL). Short-term stimulation of MSCs with GCSF positively regulated the response at the mRNA level of cytokines implicated in bone formation (BMP2), chondrogenesis (GDF9), angiogenesis (IL8, IL10) and development (NODAL) while it decreased the expression of IFNA1, which is involved in immunological responses. SDF1 stimulation uniquely regulated gene expression of the bone formation factor, BMP8b. Additionally, it stimulated the expression of an angiogenic factor (IL10) and downregulated expression of IL1 $\beta$. Similarly, as with stimulation with other factors, a cytokine involved in developmental processes, NODAL, was upregulated in response to SDF1 stimulation. The regulation of different genes indicates that the potential of MSCs can be modulated depending on the aim of the application. Interestingly, the synergic effects of SCF and GCSF on stimulating proliferation and inhibiting differentiation of rabbit MSCs have been reported (Tang et al., 2009). It would be of interest to analyse whether the combined stimulation of MSCs with all or some of factors included in this study synergises and results in an even stronger response.

\section{mRNA and secretome analysis after $48 \mathrm{~h}$ of serum- free culture}

Due to the high interest in IL1 $\beta$-regulated osteogenic differentiation (Lee et al., 2010; Mumme et al., 2012; Sonomoto et al., 2012; Ferreira et al., 2013; Loebel et al., 2014), and recent promising influence of SCF on tissue regeneration (Kim et al., 2011; Pan et al., 2013), our further investigations focused on a more detailed analysis of the direct effects of these two cytokines. We were particularly interested in regulation of cytokine genes and protein expression that could provide more predictable indications regarding the effects triggered by IL $1 \beta$ or SCF. To ensure that changes detected were specific for the stimulating factor used, and to allow for a more accurate protein analysis without contaminating serum proteins, the further investigations were performed after MSC stimulation in a serum-free medium for $48 \mathrm{~h}$. Longer periods of serumfree culture were not possible due to signs of cell distress.

Interestingly, more pronounced effects on cytokine gene expression were detected at $48 \mathrm{~h}$ serum-free culture compared to results of the analysis made $72 \mathrm{~h}$ serum containing culture. After IL1 $\beta$ stimulation, 11 cytokine genes were upregulated and 9 cytokine genes were downregulated (Fig. 3A). BMP2, BMP6, IL6, IL8 and GDF5 showed the same response to IL1 $\beta$ treatment 48 and $72 \mathrm{~h}$ after the stimulation.

SCF resulted in the upregulation of 13 cytokine genes (Fig. 3B). Only TNFSF14 and IL1 $\alpha$, but not GDF9 and NODAL gene expression were upregulated $48 \mathrm{~h}$ after SCF stimulation, whereas all of these cytokines were upregulated $72 \mathrm{~h}$ after SCF treatment. These partial variances in the response to stimulation could be attributed to the differences in the time of the analysis of gene expression, i.e., 48 or $72 \mathrm{~h}$, after the stimulation. It is highly probable that the expression of some of the genes increases or diminishes within a $24 \mathrm{~h}$ frame between both time points. In addition, the presence of serum in the initial set of experiments may also modify any response seen. 
The consistency of the data obtained from both serum containing and serum-free culture, increases the confidence in the changes observed. However, where differences were seen it must be taken into consideration that data from donors 1-4 was obtained during the serum containing $72 \mathrm{~h}$ experiment, while donors 5-9 were used for the serum-free $48 \mathrm{~h}$ experiments.

IL1 $\beta$ and SCF regulated gene expression of interleukin family members (Fig. 3). These cytokines are recognised for their pro-inflammatory role and destructive effects on bone in pathological conditions including osteoarthritis (Fernandes et al., 2002; Kapoor et al., 2011). Paradoxically, in the context of bone regeneration, the presence of some of these pro-inflammatory cytokines promotes the bone regeneration in multiple ways. Importantly, this positive effect strongly depends on the timing of their expression. Both, IL12 and IL18 inhibit in vitro osteoclast differentiation. In addition, IL18 directly induces production of IL6, which is known for its potent roles at early stages of the bone healing process (Gracie et al., 2003). In fact, IL6 together with IL8 are the major angiogenic factors stimulating vascular endothelial growth factor (VEGF) during fracture healing (Martin et al., 2009; Kolar et al., 2011). IL1 $\beta$ treatment increased the gene and protein expression of IL6 and IL8, whereas SCF had an opposite effect on gene expression of these cytokines, suggesting the involvement of IL1 $\beta$, but not SCF, in triggering angiogenesis. On the other hand, the stimulatory effects of SCF on angiogenesis could potentially be mediated through the upregulation of IL18 cytokine gene expression inducing IL6 (Gracie et al., 2003).

The gene expression of BMP superfamily members was lower in cells after IL1 $\beta$ treatment (Fig. 3A). BMPs are important for proliferation, osteoblastic and chondrogenic differentiation, morphogenesis and apoptosis. A heterodimeric association of BMP4/7 and $\mathrm{BMP} 2 / 7$ regulates the proliferation of MSCs and induces the differentiation of MSCs into osteoblastic lineage (Tsiridis et al., 2007). Similarly, BMP5 and TGF $\beta_{3}$ possess osteoinductive properties (Wozney, 2002). At the same time, BMP6, a factor implicated in chondrocyte maturation, was upregulated after the stimulation with IL1 $\beta$. GDF5 and GDF8 are involved in chondrogenesis and callus formation. Additionally, GDF8, a negative regulator of skeletal muscle growth, stimulates the adipogenic differentiation in MSCs, whereas its absence increases osteogenic differentiation (Artaza et al., 2005; Hamrick et al., 2007). Interestingly, a positive correlation of GDF8 deficiency and fracture callus size in a mouse in vivo model was reported (Kellum et al., 2009).

In addition to the assessment of cytokine genes in response to $2 \mathrm{~h}$ stimulation of cells with IL1 $\beta$ and SCF, the expression of Wnt signalling pathway components and their relation to Sox 9 and Runx 2 transcription factor gene expression was analysed after $48 \mathrm{~h}$ of serum-free culture post treatment. The analysis of Wnt 3a, 4, 5a, $7 \mathrm{~b}$ and $\beta$-catenin mRNA expression in cells stimulated with IL1 $\beta$ or SCF relative to untreated cells was strongly donor dependent. This donor variation was also seen in the expression changes of other genes. The investigation of a stimulus on multiple donors is required in order to determine the frequency with which a response is observed. This is turn provides an indication as to its potential future clinical applicability.

In the experimental setting within this study, the expression of Wnt3a was not detected in cells, neither with nor without IL1 $\beta$ or SCF stimulation. Wnt4 gene expression was detectable in control samples and in treated cells from 2 donors (5 and 8); whereas Wnt5a, 7b and $\beta$-catenin were expressed in stimulated and unstimulated cells. Both Wnt3a and Wnt4, together with $\beta$-catenin, are involved in the canonical Wnt pathway stimulating the expression of alkaline phosphatase (ALP), osteocalcin (OC), BMP2 and Runx2 (Kim et al., 2013), and inhibiting the non-canonical Wnt pathway (Boland et al., 2004). Importantly, the effect of canonical Wnt signalling on osteogenesis is highly dependent on the stage of target cells (Ling et al., 2009). Wnt5a and Wnt7b activate the non-canonical Wnt signalling pathway inducing several cascades, including planar-cell polarity (PCP), c-Jun N-terminal kinase (JNK), Nemo-like kinase (NLK) and Rho-associated kinase (ROK) signalling (Ling et al., 2009). Our results indicated that although the stimulation with IL1 $\beta$ had no significant effect on Wnt5a, Wnt7b and $\beta$-catenin gene expression, $\mathrm{Wnt} 7 \mathrm{~b}$ showed a trend of increased expression upon the treatment with IL1 $\beta$. This was in conjunction with a significant decrease in Runx 2 and Sox 9 gene expression. The treatment with SCF showed similar trends with significantly downregulated Wnt7b. The canonical Wnt signalling stimulates the differentiation of MSCs committed to osteogenic lineage, whereas it suppresses the terminal differentiation of mature osteoblasts (Ling et al., 2009). The former process is promoted through the upregulation of Runx2, which along with Sox9, is a transcriptional effector of the canonical Wnt signalling (Parr et al., 1993; Eames et al., 2004). Recent evidence showed that the promotion of osteogenic differentiation by IL1 $\beta$ is dependent on the non-canonical Wnt pathway stimulating Runx2 gene expression (Arnsdorf et al., 2009; Sonomoto et al., 2012). Although the expression of Runx 2 and Sox 9 was downregulated upon the stimulation of MSCs with IL1 $\beta$ or SCF, the Runx $2 /$ Sox 9 ratio remained at the same level suggesting that the short term treatment induces other mechanisms and outcomes in MSCs osteogenic differentiation in a monolayer culture.

Secretome analysis revealed increased levels of proteins involved in the bone formation process (Fig. 7), in response to the short-term stimulation with IL1 $\beta$ or SCF.

We observed an interesting association between the results from PCR and protein arrays regarding the expression and regulation of factors involved in fracture healing and bone remodelling. The results from post stimulation serum-free cultures showed the mRNA expression of Receptor activator of $N F-\kappa \beta$ ligand (RANKL) was downregulated, whereas at the same time TNFRSF11b was upregulated in response to the stimulation with IL1 $\beta$ or SCF. RANKL is a paracrine factor involved in osteoblast-osteoclast progenitor cells cross-talk. Secreted RANKL protein binds to RANK receptor on the osteoclast progenitor cell surface activating the differentiation of the osteoclast phenotype (Udagawa et al., 1999). Interestingly, TNFRSF11b is a gene coding the osteoprotegerin (OPG) 
protein, an inhibitor of osteoclastogenesis and activation of mature osteoclasts. In detail, OPG is the decoy receptor for RANKL expressed and secreted by osteoblasts and osteoprogenitor cells. The regulation of both OPG and RANKL is Wnt signalling dependent (Maeda et al., 2012; Maeda et al., 2013). Although, the protein level of OPG in the conditioned medium $48 \mathrm{~h}$ after the stimulation of MSCs with IL1 $\beta$ or SCF was at the same level as in untreated cells (data not shown), based on the mRNA expression level results, short term stimulation with IL1 $\beta$ or SCF strongly suggest the indirect inhibitory effects of these factors on the osteoclasts differentiation. Additionally, we reported Wnt pathway dependent regulation of OPG and RANKL in response to IL $1 \beta$ and SCF. The gene expression of additional factors inhibiting osteoclastogenesis was positively regulated in response to the stimulation. SCF treatment upregulated the expression of IL18, stimulating the production of osteoclast differentiation inhibitor, granulocyte macrophage colony-stimulating factor (GMCSF), by T-cells (Horwood et al., 1998; Gracie et al., 2003). In the case of short-term stimulation of MSCs with IL1 $\beta$, the expression of GM-SCF gene was directly upregulated after the treatment.

Understanding the mechanisms involved in the indirect effects of preconditioning, i.e., due to the enhancement of the secretion of trophic factors acting in a paracrine manner, would be of great interest for cell-based regenerative therapies. Especially the relevance of the secreted factors after the stimulation in the context of bone regeneration would aid bone tissue regeneration strategies. Hence, it is crucial to further analyse the indirect effects of shortterm stimulation in the context of bone healing within a reliable in vitro cell culture model, which in reality should mimic endochondral ossification. In fact, it is challenging to recapitulate endochondral ossification, which occurs during bone formation or fracture healing, in in vitro conditions. The conventional monolayer in vitro models focus on the direct stimulation of osteogenesis which is alike intramembranous ossification but rarely occurs in the initial phase of fracture healing. The controlled stimulation of chondrogenic differentiation, followed by the osteogenic differentiation of MSCs in a $3 \mathrm{D}$ in vitro culture, results in formation of bone tissue via endochondral ossification (Muraglia et al., 2003; Scotti et al., 2010). Such models may be more suitable for future in vitro investigations into fracture healing.

\section{Conclusions}

The regeneration of bone is triggered by factors produced during the inflammation phase that occurs after trauma. These factors influence the behaviour of cells residing at the injury site by acting in a direct and indirect manner. Our results indicate the potential of a transient stimulation of cells by a number of factors to enhance the regulation of trophic factors over longer period of time. IL1 $\beta$ strongly promoted the secretion of a wide range of proteins with chemotactic, proinflammatory and angiogenic properties, suggesting it may have a greater influence in the early bone repair environment. Whereas SCF regulated the expression of proteins involved in proliferation, chondrogenesis and ECM regulation, indicating its use may be more beneficial in either cartilage repair or callus formation. This effect was achieved by a short stimulation, which could be applied as stem cell therapy strategy and performed intra-operatively.

\section{Acknowledgements}

This investigation was financially supported with the assistance of the AO Foundation through an AOTRAUMA Network grant.

\section{References}

Arnsdorf EJ, Tummala P, Jacobs CR (2009) Noncanonical Wnt signaling and $\mathrm{N}$-cadherin related betacatenin signaling play a role in mechanically induced osteogenic cell fate. PLoS One 4: e5388.

Artaza JN, Bhasin S, Magee TR, Reisz-Porszasz S, Shen R, Groome NP, Meerasahib MF, Gonzalez-Cadavid NF (2005) Myostatin inhibits myogenesis and promotes adipogenesis in $\mathrm{C} 3 \mathrm{H}$ 10T(1/2) mesenchymal multipotent cells. Endocrinology 146: 3547-3557.

Boland GM, Perkins G, Hall DJ, Tuan RS (2004) Wnt 3a promotes proliferation and suppresses osteogenic differentiation of adult human mesenchymal stem cells. J Cell Biochem 93: 1210-1230.

Coelho MB, Cabral JM, Karp JM (2012) Intraoperative stem cell therapy. Annu Rev Biomed Eng 14: 325-349.

Czekanska EM, Stoddart MJ, Ralphs JR, Richards RG, Hayes JS (2013) A phenotypic comparison of osteoblast cell lines versus human primary osteoblasts for biomaterials testing. J Biomed Mater Res A 102: 2636-2643.

Drago D, Cossetti C, Iraci N, Gaude E, Musco G, Bachi A, Pluchino S (2013) The stem cell secretome and its role in brain repair. Biochimie 95: 2271-2285.

Eames BF, Sharpe PT, Helms JA (2004) Hierarchy revealed in the specification of three skeletal fates by Sox 9 and Runx2. Dev Biol 274: 188-200.

Fernandes JC, Martel-Pelletier J, Pelletier JP (2002) The role of cytokines in osteoarthritis pathophysiology. Biorheology 39: 237-246.

Ferreira E, Porter RM, Wehling N, O’Sullivan RP, Liu F, Boskey A, Estok DM, Harris MB, Vrahas MS, Evans CH, Wells JW (2013) Inflammatory cytokines induce a unique mineralizing phenotype in mesenchymal stem cells derived from human bone marrow. J Biol Chem 288: 29494-29505.

Gnecchi M, He H, Noiseux N, Liang OD, Zhang L, Morello F, Mu H, Melo LG, Pratt RE, Ingwall JS, Dzau VJ (2006) Evidence supporting paracrine hypothesis for Akt-modified mesenchymal stem cell-mediated cardiac protection and functional improvement. FASEB J 20: 661-669.

Gracie JA, Robertson SE, McInnes IB (2003) Interleukin-18. J Leukoc Biol 73: 213-224.

Hamrick MW, Shi X, Zhang W, Pennington C, Thakore $\mathrm{H}$, Haque M, Kang B, Isales CM, Fulzele S, Wenger KH (2007) Loss of myostatin (GDF8) function increases 
osteogenic differentiation of bone marrow-derived mesenchymal stem cells but the osteogenic effect is ablated with unloading. Bone 40: 1544-1553.

Horwood NJ, Udagawa N, Elliott J, Grail D, Okamura H, Kurimoto M, Dunn AR, Martin T, Gillespie MT (1998) Interleukin 18 inhibits osteoclast formation via $\mathrm{T}$ cell production of granulocyte macrophage colony-stimulating factor. J Clin Invest 101: 595-603.

Hsiao ST, Asgari A, Lokmic Z, Sinclair R, Dusting GJ, Lim SY, Dilley RJ (2012) Comparative analysis of paracrine factor expression in human adult mesenchymal stem cells derived from bone marrow, adipose, and dermal tissue. Stem Cells Dev 21: 2189-2203.

Hwang HJ, Chang W, Song BW, Song H, Cha MJ, Kim IK, Lim S, Choi EJ, Ham O, Lee SY, Shim J, Joung B, Pak HN, Kim SS, Choi BR, Jang Y, Lee MH, Hwang KC (2012) Antiarrhythmic potential of mesenchymal stem cell is modulated by hypoxic environment. J Am Coll Cardiol 60: 1698-1706.

Kapoor M, Martel-Pelletier J, Lajeunesse D, Pelletier JP, Fahmi H (2011) Role of proinflammatory cytokines in the pathophysiology of osteoarthritis. Nat Rev Rheumatol 7: 33-42.

Kellum E, Starr H, Arounleut P, Immel D, Fulzele S, Wenger K, Hamrick MW (2009) Myostatin (GDF-8) deficiency increases fracture callus size, Sox-5 expression, and callus bone volume. Bone 44: 17-23.

Kim JH, Liu X, Wang J, Chen X, Zhang H, Kim SH, Cui J, Li R, Zhang W, Kong Y, Zhang J, Shui W, Lamplot J, Rogers MR, Zhao C, Wang N, Rajan P, Tomal J, Statz J, Wu N, Luu HH, Haydon RC, He TC (2013) Wnt signaling in bone formation and its therapeutic potential for bone diseases. Ther Adv Musculoskelet Dis 5: 13-31.

Kim KL, Meng Y, Kim JY, Baek EJ, Suh W (2011) Direct and differential effects of stem cell factor on the neovascularization activity of endothelial progenitor cells. Cardiovasc Res 92: 132-140.

Kolar P, Gaber T, Perka C, Duda GN, Buttgereit F (2011) Human early fracture hematoma is characterized by inflammation and hypoxia. Clin Orthop Relat Res 469: 3118-3126.

Lee YM, Fujikado N, Manaka H, Yasuda H, Iwakura Y (2010) IL-1 plays an important role in the bone metabolism under physiological conditions. Int Immunol 22: 805-816.

Li Z, Kupcsik L, Yao SJ, Alini M, Stoddart MJ (2009) Chondrogenesis of human bone marrow mesenchymal stem cells in fibrin-polyurethane composites. Tissue Eng Part A 15: 1729-1737.

Ling L, Nurcombe V, Cool SM (2009) Wnt signaling controls the fate of mesenchymal stem cells. Gene 433: 1-7.

Loebel C, Czekanska EM, Staudacher J, Salzmann G, Richards RG, Alini M, Stoddart MJ (2014) The calcification potential of human MSCs can be enhanced by interleukin-1 beta in osteogenic medium. J Tissue Eng Regen Med In Press: DOI:10.1002/term.1950.

Maeda K, Kobayashi Y, Udagawa N, Uehara S, Ishihara A, Mizoguchi T, Kikuchi Y, Takada I, Kato S, Kani S, Nishita M, Marumo K, Martin TJ, Minami Y, Takahashi N (2012) Wnt5a-Ror2 signaling between osteoblast-lineage cells and osteoclast precursors enhances osteoclastogenesis. Nat Med 18: 405-412.

Maeda K, Takahashi N, Kobayashi Y (2013) Roles of Wnt signals in bone resorption during physiological and pathological states. J Mol Med (Berl) 91: 15-23.

Martin D, Galisteo R, Gutkind JS (2009) CXCL8/IL8 stimulates vascular endothelial growth factor (VEGF) expression and the autocrine activation of VEGFR2 in endothelial cells by activating NFkappaB through the CBM (Carma3/Bcl10/Malt1) complex. J Biol Chem 284: 6038-6042.

Mountziaris PM, Spicer PP, Kasper FK, Mikos AG (2011) Harnessing and modulating inflammation in strategies for bone regeneration. Tissue Eng Part B Rev 17: 393-402.

Mumme M, Scotti C, Papadimitropoulos A, Todorov A, Hoffmann W, Bocelli-Tyndall C, Jakob M, Wendt D, Martin I, Barbero A (2012) Interleukin-1beta modulates endochondral ossification by human adult bone marrow stromal cells. Eur Cell Mater 24: 224-236.

Muraglia A, Corsi A, Riminucci M, Mastrogiacomo M, Cancedda R, Bianco P, Quarto R (2003) Formation of a chondro-osseous rudiment in micromass cultures of human bone-marrow stromal cells. J Cell Sci 116: 2949-2955.

Overman JR, Farre-Guasch E, Helder MN, ten Bruggenkate CM, Schulten EA, Klein-Nulend J (2013a) Short (15 minutes) bone morphogenetic protein-2 treatment stimulates osteogenic differentiation of human adipose stem cells seeded on calcium phosphate scaffolds in vitro. Tissue Eng Part A 19: 571-581.

Overman JR, Helder MN, ten Bruggenkate CM, Schulten EA, Klein-Nulend J, Bakker AD (2013b) Growth factor gene expression profiles of bone morphogenetic protein-2-treated human adipose stem cells seeded on calcium phosphate scaffolds in vitro. Biochimie 95: 23042313.

Pan S, Dangaria S, Gopinathan G, Yan X, Lu X, Kolokythas A, Niu Y, Luan X (2013) SCF promotes dental pulp progenitor migration, neovascularization, and collagen remodeling - potential applications as a homing factor in dental pulp regeneration. Stem Cell Rev 9: 655667.

Parr BA, Shea MJ, Vassileva G, McMahon AP (1993) Mouse Wnt genes exhibit discrete domains of expression in the early embryonic CNS and limb buds. Development 119: 247-261.

Pittenger MF, Mackay AM, Beck SC, Jaiswal RK, Douglas R, Mosca JD, Moorman MA, Simonetti DW, Craig S, Marshak DR (1999) Multilineage potential of adult human mesenchymal stem cells. Science 284: 143-147.

Schlosser S, Dennler C, Schweizer R, Eberli D, Stein JV, Enzmann V, Giovanoli P, Erni D, Plock JA (2012) Paracrine effects of mesenchymal stem cells enhance vascular regeneration in ischemic murine skin. Microvasc Res 83: 267-275.

Scotti C, Tonnarelli B, Papadimitropoulos A, Scherberich A, Schaeren S, Schauerte A, Lopez-Rios J, Zeller R, Barbero A, Martin I (2010) Recapitulation of endochondral bone formation using human adult mesenchymal stem cells as a paradigm for developmental engineering. Proc Natl Acad Sci USA 107: 7251-7256. 
Simon AM, Manigrasso MB, O’Connor JP (2002) Cyclo-oxygenase 2 function is essential for bone fracture healing. J Bone Miner Res 17: 963-976.

Sonomoto K, Yamaoka K, Oshita K, Fukuyo S, Zhang X, Nakano K, Okada Y, Tanaka Y (2012) Interleukin-1beta induces differentiation of human mesenchymal stem cells into osteoblasts via the Wnt-5a/receptor tyrosine kinaselike orphan receptor 2 pathway. Arthritis Rheum 64: 33553363.

Tang FP, Wu X, Yu X, Yang S, Xu W, Li J (2009) Effects of granulocyte colony-stimulating factor and stem cell factor, alone and in combination, on the biological behaviours of bone marrow mesenchymal stem cells. JBiSE 2: 200-207.

Tsiridis E, Upadhyay N, Giannoudis P (2007) Molecular aspects of fracture healing: which are the important molecules? Injury 38 Suppl 1: S11-25.

Udagawa N, Takahashi N, Jimi E, Matsuzaki K, Tsurukai T, Itoh K, Nakagawa N, Yasuda H, Goto M, Tsuda
E, Higashio K, Gillespie MT, Martin TJ, Suda T (1999) Osteoblasts/stromal cells stimulate osteoclast activation through expression of osteoclast differentiation factor/ RANKL but not macrophage colony-stimulating factor: receptor activator of NF-kappa B ligand. Bone 25: 517-523.

Wozney JM (2002) Overview of bone morphogenetic proteins. Spine (Phila Pa 1976) 27: S2-8.

Zhukareva V, Obrocka M, Houle JD, Fischer I, Neuhuber B (2010) Secretion profile of human bone marrow stromal cells: donor variability and response to inflammatory stimuli. Cytokine 50: 317-321.

Editor's Note: All questions/comments by the reviewers were answered by text changes. There is hence no Discussion with Reviewers section. 